\title{
Factors affecting the quality of cardiopulmonary resuscitation in inpatient units: perception of nurses*
}

\author{
Fatores que comprometem a qualidade da ressuscitação cardiopulmonar \\ em unidades de internação: percepção do enfermeiro \\ Factores que comprometen la calidad de la reanimación cardiopulmonar \\ en unidades de estancia hospitalaria: percepción del enfermero
}

Clairton Marcos Citolino Filho',2, Eduesley Santana Santos ${ }^{2}$, Rita de Cassia Gengo e Silva ${ }^{1}$, Lilia de Souza Nogueira ${ }^{1}$

\footnotetext{
* Extracted from the residence final paper "Fatores que comprometem a qualidade da ressuscitação cardiopulmonar em unidades de internação: percepção do enfermeiro", Residência em Enfermagem em Cardiopneumologia de Alta Complexidade, Escola de Enfermagem, Instituto do Coração, Hospital das Clínicas, Faculdade de Medicina, Universidade de São Paulo, 2015.

${ }^{1}$ Universidade de São Paulo, Escola de Enfermagem, São Paulo, SP, Brazil.

${ }^{2}$ Universidade de São Paulo, Faculdade de Medicina, Hospital das Clínicas, Instituto do Coração, São Paulo, SP, Brazil.
}

\begin{abstract}
Objective: To identify, in the perception of nurses, the factors that affect the quality of cardiopulmonary resuscitation $(\mathrm{CPR})$ in adult inpatient units, and investigate the influence of both work shifts and professional experience length of time in the perception of these factors. Method: A descriptive, exploratory study conducted at a hospital specialized in cardiology and pneumology with the application of a questionnaire to 49 nurses working in inpatient units. Results: The majority of nurses reported that the high number of professionals in the scenario (75.5\%), the lack of harmony $(77.6 \%)$ or stress of any member of staff (67.3\%), lack of material and/or equipment failure $(57.1 \%)$, lack of familiarity with the emergency trolleys (98.0\%) and presence of family members at the beginning of the cardiopulmonary arrest assistance $(57.1 \%)$ are factors that adversely affect the quality of care provided during CPR. Professional experience length of time and the shift of nurses did not influence the perception of these factors. Conclusion: The identification of factors that affect the quality of CPR in the perception of nurses serves as parameter to implement improvements and training of the staff working in inpatient units.
\end{abstract}

DESCRIPTORS

Heart Arrest; Cardiopulmonary Resuscitation; Emergency Nursing; Impatient Care Units. 


\section{INTRODUCTION}

Cardiopulmonary arrest $(\mathrm{CPA})$ is the cessation of cardiac and respiratory functions, when the body cells and tissues stop receiving the oxygen and nutrients needed to sustain life. If not reversed quickly, the cessation of these functions leads to irreversible cell and brain damage, causing death rapidly ${ }^{(1-2)}$.

In Brazil, the occurrence of CPA is estimated at around 200,000 per year, $50 \%$ of which are in hospital events ${ }^{(2)}$. International studies show that the Pulseless Electrical Activity (PEA) and asystole are the initial rhythms most diagnosed at the time of in hospital CPA, followed by Ventricular Fibrillation (VF) and pulseless Ventricular Tachycardia $(\mathrm{pVT})$, and the last two are associated with lower mortality rates of the victims ${ }^{(3-4)}$.

The survival of cardiac arrest patients depends on several factors such as the integration of basic and advanced cardiac life support, in addition to post resuscitation care. The initial treatment to patients in CPA should involve a systematic approach based on the five links of the chain of survival: early detection of an individual in CPA, immediate request for expert help, start of Cardiopulmonary Resuscitation (CPR) through effective chest compressions, airway opening and oxygen delivery, and in the presence of $\mathrm{pVT}$ and VF rhythms, make early defibrillation and offer effective advanced life support and integrated post-cardiopulmonary arrest care ${ }^{(1-2)}$.

The InterAmerican Heart Foundation recommends that healthcare professionals receive continuous training focused on assistance to patients in CPA, and suggests its dissemination evenly through standardization of procedures and techniques. This recommendation emphasizes that training improves the quality of service to CPA patient, since it will be performed faster, and in a more organized, calm and effective way. In addition, the Foundation advises on the importance of the presence of all materials and equipment necessary for the care to avoid the failure of resuscitation resulting from the lack of any of these items ${ }^{(5)}$.

Since nurses provide care to patients 24 hours a day and have technical and scientific knowledge skills, in most cases they are the first professionals to recognize this event in inpatient units, starting CPR through basic life support and calling the Rapid Response Team (RRT) or the staff for the start of advanced life support actions ${ }^{(6-7)}$. Given this fact, nurses need to be agile professionals, with fast clinical reasoning, technical skills and emotional control to act in face of an emergency ${ }^{(7)}$.

However, not only the professional features described above and staff training are crucial to guarantee the quality of CPR. Factors such as the professionals' ability to manage stress during care and the guarantee of harmony and sync of the whole multidisciplinary team are essential to achieve excellence of patient care in in hospital $\mathrm{CPA}^{(8)}$.

The American Heart Association (AHA) corroborates this statement and to achieve success in CPR, they emphasize the necessity of professional training in Advanced Cardiovascular Life Support (ACLS) and the performance of several tasks simultaneously, requiring staff efficiency in communication and dynamism in service, facilitated by the intervention of a leader with the main objectives of organizing the group, assisting each team member and acting as the facilitator in the execution of tasks at the time of $\mathrm{CPA}^{(1)}$.

This event is expected to happen less often in the context of medical and surgical wards (inpatient units), since patients tend not to have a critical health status and consequently, have better clinical stability than those in critical care units. Therefore, knowing the opinion of professionals of medical and surgical wards on aspects that hinder CPR is key for establishing improvement strategies.

Considering that success in assistance to patients in CPA depends on knowledge and scientific-technical and interpersonal skills, and little is known in the literature about the factors that compromise the care of these patients from the perception of professionals involved in care, we justify the conduction of this study, which used the following guiding question: In the perception of nurses, what are the main factors affecting the quality of CPR performed on patients admitted to medical and surgical wards?

The aim of the study was to identify, in the perception of nurses, the factors affecting the quality of care for patients in CPA in inpatient units, and analyze the influence of work shifts and professional experience length of time on the perception of these factors.

\section{METHOD}

This is a descriptive, exploratory study, conducted from August to September 2014 at the Instituto do Coração do Hospital das Clínicas, Faculdade de Medicina, Universidade de São Paulo (InCor/HCFMUSP), a high complexity public hospital specialized in cardiology and pneumology, in São Paulo, Brazil.

Participants were selected based on the following inclusion criteria: being a clinical nurse in the adult medical and surgical wards, having provided assistance for at least a CPA patient in these units, and agreeing to participate in the study by signing the informed consent.

The nursing board of the hospital provided a list containing the names of all nurses working in the medical or surgical wards of adult patients. Among the 63 nurses on the list, 51 were approached and agreed to participate in the study. Twelve nurses were not included because they were on leave or vacation during the data collection.

Data were collected by applying a questionnaire containing closed questions related to the sociodemographic and professional profile of the nurses and their perception when caring for patients presenting in hospital CPA. The questionnaire was given to the nurses by one of the researchers at the beginning of their shift and collected after a period arranged with each participant according to their convenience.

Data were stored in a Microsoft Excel 2010 spreadsheet and then exported to the Statistical Package for the Social Sciences (SPSS), version 22.

The variables were analyzed by descriptive and inferential statistics. The Pearson's chi-squared and the Fisher's exact tests were used for the comparison of groups (day or night shift). The Mann-Whitney test was used to com- 
pare the average of professional experience length of time in relation to the study variables. In all analyzes was set a significance level of $5 \%$.

The development of the study met the national and international standards of ethics in research involving human subjects, and was approved by the Ethics Committee, Escola de Enfermagem, Universidade de São Paulo (CAAE: 30903614.2.0000.5392), with consent of the Ethics Committee for Analysis of Research projects (CAPPesq), linked to the InCor/HCFMUSP.

\section{RESULTS}

Of the 51 professionals invited to participate in the study, two did not return the completed questionnaire. Therefore, the final sample consisted of 49 nurses. Of these, 44 (89.8\%) were female, with mean age of 38.1 years
(SD 9.9). The mean time of continuous training and professional experience was 11.9 years (SD 8.3) and 10.9 years (SD 8.8), respectively, and 23 nurses (46.9\%) had more than ten years of experience in the nursing field. A total of 47 nurses (95.6\%) reported having had previous training related to CPA care during undergraduate education and 36 (73.5\%) had attended Lato Sensu Postgraduate education (equivalent to specialization) in Emergency Care, Intensive Care and Cardiology. Regarding the ACLS course, 44 $(89.8 \%)$ nurses were certified and $93.9 \%$ considered that they were updated on the 2010 AHA CPR guidelines.

Table 1 shows the descriptive analysis of the nurses' responses regarding their perception of caring for patients in CPA in medical and surgical wards, as well as the result of the comparison between groups (work shifts) according to the study variables.

Table 1 - Comparison of groups (professionals' work shifts) according to variables related to the perception of nurses about CPA care at inpatient units - São Paulo, SP, Brazil, 2014.

\begin{tabular}{|c|c|c|c|c|}
\hline \multirow[b]{2}{*}{ Variables } & \multicolumn{2}{|c|}{ Work shift } & \multirow[b]{2}{*}{ p-value } & \multirow[b]{2}{*}{$\begin{array}{l}\text { Total } \\
\text { n }(\%)\end{array}$} \\
\hline & $\begin{array}{c}\text { Day } \\
\text { n (\%) }\end{array}$ & $\begin{array}{l}\text { Night } \\
\text { n (\%) }\end{array}$ & & \\
\hline \multicolumn{5}{|l|}{$\begin{array}{l}\text { High number of professionals }(>6) \text { when caring for } \\
\text { patients in CPR }\end{array}$} \\
\hline Helps the assistance & $6(18.8)$ & $5(29.4)$ & \multirow{3}{*}{$0.664^{*}$} & $11(22.4)$ \\
\hline Disturbs the assistance & $25(78.1)$ & $12(70.6)$ & & $37(75.5)$ \\
\hline Indifferent & $1(3.1)$ & - & & $1(2.1)$ \\
\hline \multicolumn{5}{|l|}{ Presence of a leader in the scenario } \\
\hline Improves the quality of CPR & $31(96.9)$ & $15(88.2)$ & \multirow{2}{*}{$0.273^{*}$} & $46(93.9)$ \\
\hline Does not affect the quality of CPR & $1(3.1)$ & $2(11.8)$ & & $3(6.1)$ \\
\hline \multicolumn{5}{|l|}{ Lack of harmonious team relationship } \\
\hline Interferes in the quality of CPR & $25(78.1)$ & $13(76.5)$ & \multirow{2}{*}{$1.000^{*}$} & $38(77.6)$ \\
\hline Does not affect the quality of CPR & $7(21.9)$ & $4(23.5)$ & & $11(22.4)$ \\
\hline \multicolumn{5}{|l|}{ Lack of material and/or equipment failure } \\
\hline Interferes in the quality of CPR & $19(59.4)$ & $9(52.9)$ & \multirow{2}{*}{$0.665^{* *}$} & $28(57.1)$ \\
\hline Does not affect the quality of CPR & $13(40.6)$ & $8(47.1)$ & & $21(42.9)$ \\
\hline \multicolumn{5}{|l|}{ Lack of familiarity with emergency trolley } \\
\hline Compromises the assistance & 31 (96.9) & $17(100.0)$ & \multirow{2}{*}{$1.000^{*}$} & $48(98.0)$ \\
\hline Does not compromise the assistance & $1(3.1)$ & - & & $1(2.0)$ \\
\hline \multicolumn{5}{|l|}{ Presence of family member during CPR } \\
\hline Interferes in the start of the attendance & $18(56.2)$ & $10(58.8)$ & \multirow{2}{*}{$0.862^{* *}$} & $28(57.1)$ \\
\hline Does not affect the start of the attendance & $14(43.8)$ & $7(41.2)$ & & $21(42.9)$ \\
\hline \multicolumn{5}{|l|}{ Personal stress } \\
\hline Hinders the performance during CPR & $4(12.5)$ & $5(29.4)$ & \multirow{2}{*}{$0.244^{*}$} & $9(18.4)$ \\
\hline Does not hinder the performance during CPR & $28(87.5)$ & $12(70.6)$ & & $40(81.6)$ \\
\hline \multicolumn{5}{|l|}{ Stress of any team member } \\
\hline Interferes in the quality of CPR & $24(75.0)$ & $9(52.9)$ & \multirow{2}{*}{$0.117^{* *}$} & $33(67.3)$ \\
\hline Does not affect the quality of CPR & $8(25.0)$ & $8(47.1)$ & & $16(32.7)$ \\
\hline
\end{tabular}

* Fisher's exact test.

** Pearson's chi-squared test.

In the perception of nurses, the high number of professionals (above six) during CPR disturbs the assistance (75.5\%), and almost all professionals (93.9\%) stressed that the presence of a leader improves the quality of care to a patient in CPA. Participants also emphasized that the lack of a harmonious relationship among team members $(77.6 \%)$, lack of material and/or equipment failure (57.1\%), lack of familiarization with the emergency trolley (98.0\%), the presence of a family member of the patient at the moment of CPA (57.1\%) or the stress of a team member dur- 
ing the assistance $(67.3 \%)$ interfere in the quality of CPR performed on patients in the inpatient unit. According to the majority of professionals (81.6\%), the personal stress generated during the recognition of a patient in CPA does not disturb the self-performance during CPR (Table 1).

The comparative analysis of groups (work shifts) showed no significant association between them in relation to other variables (Table 1 ).

The comparative analysis of the average of professional experience length of time according to variables related to the perception of nurses about caring for patients in CPA in medical and surgical wards is shown in table 2 .

Table 2 - Comparison of the average of professional experience length of time according to variables related to the perception of nurses about CPA care at inpatient units - São Paulo, SP, Brazil, 2014.

\begin{tabular}{|c|c|c|c|}
\hline \multirow{2}{*}{ Variables } & \multicolumn{3}{|c|}{ Professional experience length of time } \\
\hline & Mean (SD) & Median (min-max) & $\mathbf{p}^{*}$ \\
\hline \multicolumn{4}{|l|}{ High number of professionals ( $>6$ ) during CPR } \\
\hline Helps the assistance & $14.6(11.4)$ & $11.9(2-31.5)$ & \multirow{3}{*}{0.350} \\
\hline Disturbs the assistance & $10.2(7.9)$ & $8.0(1.0-32.5)$ & \\
\hline Indifferent & $2.4(-)$ & 2.4 & \\
\hline \multicolumn{4}{|l|}{ Presence of a leader in the scenario } \\
\hline Improves the quality of CPR & $10.9(8.8)$ & $8.8(1.0-32.5)$ & \multirow{2}{*}{0.851} \\
\hline Does not affect the quality of CPR & $11.6(11.0)$ & $8.0(2.9-24.0)$ & \\
\hline \multicolumn{4}{|l|}{ Lack of harmonious team relationship } \\
\hline Interferes in the quality of CPR & $11.24(9.1)$ & $8.0(1.0-32.5)$ & \multirow{2}{*}{0.632} \\
\hline Does not affect the quality of CPR & $9.9(8.1)$ & $10.4(1.6-24.0)$ & \\
\hline \multicolumn{4}{|l|}{ Lack of material and/or equipment failure } \\
\hline Interferes in the quality of CPR & $11.7(9.5)$ & $9.0(1.3-32.5)$ & \multirow{2}{*}{0.621} \\
\hline Does not affect the quality of CPR & $9.9(7.9)$ & $8.0(1.0-24.0)$ & \\
\hline \multicolumn{4}{|l|}{ Lack of familiarity with emergency trolley } \\
\hline Compromises the assistance & $11.1(8.9)$ & $8.8(1.0-32.5)$ & \multirow{2}{*}{0.479} \\
\hline Does not compromise the assistance & $4.6(-)$ & 4.6 & \\
\hline \multicolumn{4}{|l|}{ Presence of family member during CPR } \\
\hline Interferes in the start of the attendance & $10.3(8.3)$ & $7.0(1.3-31.5)$ & \multirow{2}{*}{0.762} \\
\hline Does not affect the start of the attendance & $11.8(9.6)$ & $11.7(1.0-32.5)$ & \\
\hline \multicolumn{4}{|l|}{ Personal stress } \\
\hline Hinders the performance during CPR & $8.4(7.8)$ & $5.7(2.0-11.7)$ & \multirow{2}{*}{0.409} \\
\hline Does not hinder the performance during CPR & $11.5(9.0)$ & $9.8(1.0-32.5)$ & \\
\hline \multicolumn{4}{|l|}{ Stress of any team member } \\
\hline Interferes in the quality of CPR & $10.5(9.3)$ & $7.0(1.3-32.5)$ & \multirow{2}{*}{0.412} \\
\hline Does not affect the quality of CPR & $11.9(8.0)$ & $12.45(1.0-24.0)$ & \\
\hline
\end{tabular}

*Mann-Whitney test

Nurses with longer time of professional experience pointed the following aspects that interfere in the quality of CPR: lack of harmonious relationship among the team members, lack of material and/or equipment failure during the service, and lack of familiarity with emergency trolley. They also stated that the high number of professionals during the assistance, the presence of a leader or a family member during CPR, as well as the stress of a team member do not influence the quality of care. However, data in table 2 show that there were no differences between the average of professional experience length of time regarding the variables related to the perception of CPA care at the inpatient unit $(\mathrm{p}>0.05)$.

\section{DISCUSSION}

The successful performance of CPR depends on continuous professional training, by acquiring sufficient knowledge, skills and abilities to initiate CPR maneuvers effectively ${ }^{(9)}$. These factors, associated with the organized working environment and especially the harmony and synchronism of the whole team, contribute to the excellence of care to patients in in hospital $\mathrm{CPA}^{(8)}$.

Researchers investigated the nursing staff working in medical wards and identified the lack of professionals as one of the main negative interferences faced during the care of a patient in $\mathrm{CPA}^{(10)}$. The present study showed that the excess of professionals also interferes negatively on the quality of CPR provided. This experience of nurses may be related to the characteristic of the institution of this research: a university hospital that often receives students from different courses in the health area, greatly increasing the number of health professionals in learning process at medical and surgical wards.

Still regarding the team, CPR guidelines published by the Sociedade Brasileira de Cardiologia reinforce that the two fundamental principles of teamwork are leadership 
and communication. The leader must be the professional who centralizes the communication among team members and takes over the management of the case, ensuring that all tasks are understood and implemented correctly ${ }^{(2)}$. This recommendation reinforces the perception of the majority of nurses in the study (93.9\%) about the importance of this professional in improving the quality of CPR.

A staff in harmony, well-trained and with leadership is vital to maintain the quality of CPA care ${ }^{(8,11)}$. Among all interviewed nurses, $77.6 \%$ stated that the lack of a harmonious relationship in the team negatively affects the care provided to patients in CPA. A study conducted in São Paulo, Brazil, showed that one of the most common behaviors during $\mathrm{CPR}$ is the lack of activity coordination, and that harmony is essential for the effective and coordinated care ${ }^{(12)}$.

As important as the presence of trained professionals and a harmonious relationship among the team in the scenario of CPA, is the availability of all essential materials and equipment for the safe and effective care.

In this sense, essential materials and equipment (classified as level 1) for CPA care must be available immediately upon request, and those highly recommended (classified as level 2) must be available within 15 minutes after the request ${ }^{(13)}$.

Twenty-eight professionals of the study (57.1\%) reported that the lack of material and/or the failure of some equipment during CPA care interferes in the quality of CPR. This result is corroborated in other studies ${ }^{(12,14-15)}$.

Researchers analyzed the emergency trolleys of two university hospitals and found that all had lack of some equipment that compromised the care delivered to patients in $\mathrm{CPA}^{(14)}$. A study carried out in an Intensive Care Unit showed that among all difficulties found during CPA care, $31 \%$ were related to problems of material resources ${ }^{(12)}$.

A study conducted in England compared the conditions of the emergency trolleys of three institutions before and after the intervention (sealing of trays for airway and venipuncture procedures). It found that only an emergency trolley was in accordance with the recommendations of that country before intervention, and the majority contained expired, missing or in-excess items. Three years after implementing the sealing of trays, all emergency trolleys analyzed were in accordance with the established standards ${ }^{(15)}$. This showed the importance of standardization and the strategy of sealing trays of procedures to ensure the suitable material for CPA care.

Corroborating this finding, the Sociedade Brasileira de Cardiologia recommends the standardization of emergency trolleys to maintain the same contents and quantity of material in the different hospital units, allowing a quick and organized emergency care without waste ${ }^{(13)}$.

In addition to the standardization, a Spanish descriptive study showed that is of great importance that both nursing staff and all team become familiar with the emergency trolley ${ }^{(16)}$. In this study, nurses stated that the lack of this familiarity interferes in the quality of care because it may cause delays in the availability of the necessary materials. A study conducted in Denmark that analyzed a database about patient safety showed that equipment failure (16.0\%) and unavailable resuscitation material (11.0\%) were among the 122 critical incidents identified during CPA care ${ }^{(17)}$.

In the present study, an equitable distribution of answers regarding the presence of family members during CPR was found: $57.1 \%$ of nurses reported that the presence of a family member delays the beginning of CPR, and $42.9 \%$ did not consider that it affects the start of CPR. Other studies show similar findings: while ones show that the presence of family members during CPR is assessed as beneficial by nurses and/or team members ${ }^{(18-20)}$, others show that professionals do not approve it, have no opinion about the matter or never experienced it ${ }^{(20-21)}$.

In this study, we identified that the personal stress generated during the identification of an emergency did not disturb the performance of most nurses when caring for a patient in CPA. However, when a team member felt stressed during assistance, there was interference in the quality of CPR, in the perception of these professionals. A study conducted in São Paulo, Brazil, found that stress and nervousness were present in most accounts of nursing professionals when asked about the existence of these emotions during $\mathrm{CPR}^{(12)}$.

As identified in the study, the work shift (day or night) and the professional experience length of time did not influence the perception of nurses in relation to the factors that compromise the quality of CPR in adult inpatient units. This finding may be associated to several factors: nearly half of the professionals in the sample had more than ten years of experience in the nursing field; the institution conducts continuous training, enabling professionals to perform CPR with quality; approximately $90.0 \%$ of nurses had the ACLS course certification; and the RRT is implemented in the hospital, assisting clinical emergencies and CPA in medical and surgical wards with greater agility, 24 hours a day. Some studies show that the care of patients with worsening clinical picture and/or CPA provided by the RRT has generated great benefits, such as reducing hospital mortality rates, reducing the severity of patients admitted to the Intensive Care Unit after CPR, and reduced number of patients with clinical instability evolving for $\mathrm{CPA}^{(22-23)}$.

In applying the results of this study, some limitations should be considered: the sample included nurses from a single institution, a reference center for the care of patients with cardiopulmonary diseases, which compromises the generalization of the results. Moreover, the small number of research participants must be considered.

\section{CONCLUSION}

This study has found that, in the perception of nurses, the main factors that negatively influence the quality of CPR in adult inpatient units are: high number of professionals on the scenario, disharmony or stress of any staff member, lack of materials and/or equipment failure, lack of familiarity with the emergency trolley and presence of a family member at the beginning of attendance. Professionals highlighted that personal stress does not disturb the self-performance during the care and that the presence of 
a leader improves the quality of CPR. The professional experience length of time and the nurses' work shift did not influence on the perception of these factors.
The results of the study serve as parameters for the implementation of improvements and training of staff working in inpatient units.

\section{RESUMO}

Objetivo: Identificar, na percepção dos enfermeiros, os fatores que comprometem a qualidade da ressuscitação cardiopulmonar (RCP) em unidades de internação adulto e verificar a influência do turno de trabalho e do tempo de experiência dos profissionais na percepção destes fatores. Método: Estudo descritivo, exploratório, realizado em hospital especializado em cardiopneumologia com a aplicação de questionário a 49 enfermeiros que atuavam em unidades de internação. Resultados: A maioria dos enfermeiros relatou que elevado número de profissionais no cenário $(75,5 \%)$, falta de harmonia $(77,6 \%)$ ou estresse de algum membro da equipe $(67,3 \%)$, falta de material e/ou falha de equipamento $(57,1 \%)$, falta de familiarização com o carrinho de emergência (98,0\%) e presença de familiar no início do atendimento da parada cardiorrespiratória $(57,1 \%)$ são fatores que interferem negativamente na qualidade da assistência prestada durante a RCP. O tempo de experiência profissional e o turno de trabalho dos enfermeiros não exerceram influência na percepção destes fatores. Conclusão: A identificação dos fatores que comprometem a qualidade da RCP, na percepção dos enfermeiros, serve de parâmetro para implantação de melhorias e de capacitação das equipes que atuam em unidades de internação.

\section{DESCRITORES}

Parada Cardíaca; Ressuscitação Cardiopulmonar; Enfermagem em Emergência; Unidades de Internação.

\section{RESUMEN}

Objetivo: Identificar, en la percepción de los enfermeros, los factores que comprometen la calidad de la reanimación cardiopulmonar (RCP) en unidades de estancia adulta y verificar la influencia del turno de trabajo y el tiempo de experiencia de los profesionales en la percepción de dichos factores. Método: Estudio descriptivo, exploratorio, llevado a cabo en hospital especializado en cardioneumología con aplicación de cuestionario a 49 enfermeros que actuaban en unidades de estancia hospitalaria. Resultados: La mayoría de los enfermeros relataron que un elevado número de profesionales en el escenario (75,5\%), falta de armonía (77,6\%) o estrés de algún miembro del equipo $(67,3 \%)$, falta de material o/y falta de equipo $(57,1 \%)$, falta de familiarización con el carro de paro (98,0\%) y presencia de familiar en el inicio de la atención del paro cardiorrespiratorio $(57,1 \%)$ son factores que interfieren negativamente en la calidad de la asistencia prestada durante la RCP. El tiempo de experiencia profesional y el turno de trabajo de los enfermeros no ejercieron influencia en la percepción de esos factores. Conclusión: La identificación de los factores que comprometen la calidad de la $\mathrm{RCP}$, en la percepción de los enfermeros, sirve de parámetro para la implantación de mejorías y capacitación de los equipos que actúan en unidades de estancia hospitalaria.

\section{DESCRIPTORES}

Paro Cardíaco; Resucitación Cardiopulmonar; Enfermería de Urgencia; Unidades de Internación.

\section{REFERENCES}

1. American Heart Association. Suporte avançado de vida em cardiologia: manual do profissional. São Paulo: Sesil; 2012.

2. Gonzalez MM, Timerman S, Oliveira RG, Polastri TF, Dallan LAP, Araújo S, et al. I Diretriz de Ressuscitação Cardiopulmonar e Cuidados Cardiovasculares de Emergência da Sociedade Brasileira de Cardiologia: resumo executivo. Arq Bras Cardiol. 2013;100(2):105-13.

3. Meaney PA, Nadkarni VM, Kern KB, Indik JH, Halperin HR, Berg RA. Rhythms and outcomes of adult in-hospital cardiac arrest. Crit Care Med. 2010;38(1):101-8.

4. Nolan JP, Soar J, Smith GB, Gwinnutt C, Parrott F, Power S, et al. Incidence and outcome of in-hospital cardiac arrest in the United Kingdom National Cardiac Arrest Audit. Resuscitation. 2014;85(8):987-92.

5. American Heart Association; Fundação Interamericana do Coração. SBV para profissionais de saúde: manual do aluno. São Paulo: Sesil; 2011.

6. Hunziker S, Tschan F, Semmer NK, Howell MD, Marsch S. Human factors in resuscitation: Lessons learned from simulator studies. J Emerg Trauma Shock. 2010;3(4):389-94.

7. Alves CA, Barbosa CSS, Faria HTG. Cardiorespiratory arrest and nursing: the knowledge on Basic Life Support. Cogitare Enferm. 2013;18(2): 296-301.

8. Sjoberg F, Schonning E, Salzmann-Erikson M. Nurses' experiences of performing cardiopulmonary resuscitation in intensive care units: a qualitative study. J Clin Nurs. 2015 Apr 16. [Epub ahead of print]

9. Källestedt ML, Berglund A, Herlitz J, Leppert J, Enlund M. The impact of CPR and AED training on healthcare professionals' self-perceived attitudes to performing resuscitation. Scand J Trauma Resusc Emerg Med. 2012;20:26.

10. Sá CMS, Souza NVDO, Lisboa MTL, Tavares KFA. Organização do trabalho e seus reflexos na atuação dos trabalhadores de enfermagem em ressuscitação cardiopulmonar. Rev Enferm UERJ. 2012;20(1):50-5.

11. Plagisou L, Tsironi M, Zyga S, Moisoglou I, Maniadakis N, Prezerakos P. Assessment of nursing staff's theoretical knowledge of cardiovascular resuscitation in an NHS public hospital. Hellenic J Cardiol. 2015;56(2):149-53.

12. Silva SC, Padilha KG. Cardiopulmonary resuscitation in the intensive care unit: analysis of iatrogenic occurrences during attendance. Rev Esc Enferm USP. 2000;34(4):413-20.

13. Gomes AG, Garcia AM, Schmidt A, Mansur AP, Vianna CB, Ferreira D, et al. Diretriz de apoio ao suporte avançado de vida em cardiologia Código Azul: registro de ressuscitação normatização do carro de emergência. Arq Bras Cardiol. 2003;81 Supl. 4:3-14. 
14. Lima SG, Diniz LR, Nunes Filho EO, Oliveira MF, Oliveira JAV, Sá MPBO, et al. Emergency trolleys and advanced life support. Rev Bras Clin Med. 2010;8(5):399-404

15. Davies M, Couperb K, Bradley J, Baker A, Husselbee N, Woolley S, et al. A simple solution for improving reliability of cardiac arrest equipment provision in hospital. Resuscitation. 2014;85(11):1523-6.

16. Macias CC, López-Herce CJ, Alvarez AC, Martínez BE. Material for the pediatric resuscitation trolley. An Pediatr. 2007;66(1):51-4.

17. Andersen PO, Maaløe R, Andersen HB. Critical incidents related to cardiac arrests reported to the Danish Patient Safety Database. Resuscitation. 2010;81(3):312-6.

18. Orso MSD, Concha PJ. Presencia familiar durante la reanimación cardiopulmonar: la mirada de enfermeros y familiares. Cienc Enferm. 2012;18(3):83-99.

19. Jabre P, Belpomme V, Azoulay E, Jacob L, Bertrand L, Lapostolle F, et al. Family Presence during Cardiopulmonary Resuscitation. N Engl J Med. 2013;368(11):1008-18.

20. Axelsson AB, Fridlund B, Moons P, Martensson J, Reimer WS, Smith K, et al. European cardiovascular nurses' experiences of and attitudes towards having family members present in the resuscitation room. Eur J Cardiovasc Nurs. 2010;9(1):15-23.

21. Porter JE, Cooper SJ, Sellick K. Family presence during resuscitation (FPDR): perceived benefits, barriers and enablers to implementation and practice. Int Emerg Nurs. 2014;22(2):69-74.

22. Chen J, Ou L, Hillman K, Flabouris A, Bellomo R, Hollis SJ, et al. The impact of implementing a rapid response system: a comparison of cardiopulmonary arrests and mortality among four teaching hospitals in Australia. Resuscitation. 2014;85(9):1275-81.

23. Al-Qahtani S, Al-Dorzi HM, Tamim HM, Hussain S, Fong L, Taher S, et al. Impact of an intensivist-led multidisciplinar extended rapid response team on hospital-wide cardiopulmonar arrests and mortality. Crit Care Med. 2013;41(2):506-17. 